\title{
PENGARUH PENGGUNAAN HEWAN UJI YANG SAMA SECARA BERULANG PADA PENGUJIAN KOROSI DERMAL
}

\section{THE EFFECT OF USING THE SAME INDIVIDUAL TESTING ANIMAL ONREPEATED DERMAL CORROSION TEST}

\author{
Retno Puji Lestari dan Andriantoro ${ }^{1}$
}

(Diterima tanggal 23 Januari 2018; Disetujui tanggal 21 Maret 2018)

\begin{abstract}
ABSTRAK
Salah satu prosedur untuk menentukan limbah bahan berbahaya dan beracun (B3) adalah dengan melakukan pengujian korosifitas. Pengujian toksisitas limbah dengan metode akut dermal digunakan untuk melihat efek merugikan yang muncul setelah melakukan pemaparan limbah dengan bersentuhan langsung. Kulit akan terindikasi dengan adanya efek korosif dan iritasi secara topikal maupun lokal.Pengujian korosi dermal dilakukan berdasarkan Organization for Economic Cooperation and Development (OECD) Guideline No. 404 menggunakan hewan uji kelinci. Sampel limbah yang tidak diketahui asalnya dan kontrol positif berupa deterjen dipaparkan pada posisi punggung kelinci yang telah dicukur dengan area 2,5 x 2,5 cm. Pengamatan dilakukan untuk melihat timbulnya bengkak maupun ruam kemerahan akibat reaksi sampel dengan kulit dievaluasi pada 4, 24, 48, dan 72 jam setelah pengujian. Kajian dengan menggunakan hewan uji yang sama secara berulang pada pengujian korosi dermal ini dilakukan karena adanya isu kesejahteraan hewan dalam studi toksikologi. Hasil pengamatan visual menunjukkan bahwa pengujian sampel limbah tidak menimbulkan efek korosif pada hewan uji. Pengujian dengan sampel deterjen dimaksudkan untuk mendapatkan informasi mengenai penilaian tingkat korosifitas. Pengujian menggunakan hewan yang sama dilakukan berselang 30 hari. Pengujian pertama memberikan hasil iritasi kategori 2, iritan bagian i, yaitu skor ratarata untuk erythrema/oedema $\geq 2,3$ sampai $\leq 4,0$. Sementara pengujian kedua menunjukkan iritasi kategori 3 , yaitu iritasi ringan. Dengan demikian hewan uji tersebut menunjukkan adanya efek resisten terhadap sampel deterjen dan memberikan respon yang kurang sensitife terhadap sampel yang sama.
\end{abstract}

Kata kunci: uji korosi, iritasi, dermal, kelinci, ruam kemerahan, bengkak

\begin{abstract}
One of the procedures to determine the hazardous and toxic material waste is by conducting the corrosive testing. The testing of waste toxicity by acute dermal method is applied to recognize the adverse effects that occur after exposing the waste by direct contact. It will be indicated by corrosive or irritated effects, either topically or locally. Dermal corrosion testing is conducted under OECD Guideline no 404 using rabbit. Unknown waste sample and detergent as positive control were exposed to the shaved-dorsal part of rabbit with the area of $2.5 \times 2.5 \mathrm{~cm}$. Observation wasperformed to recognize the symptom of oedema and erythrema as a result of sample's reaction with skin and was being evaluated after 4, 24, 48, and 72 hours. In this study, dermal corrosion testing was performed using the same test animal due to animal welfare issues in toxicology study. The visual result showed that waste sample did not generate the corrosive effect on animal test. The experiment using detergent sample are intended to obtain some information after the assessment of corrosive level. The testing with the same animal was carried out after 30 days later. The first test presented the category 2, irritant part $i$, with the average score for erythrema/oedema $\geq$ 2,3 to $\leq 4,0$. While the second testing showed category 3, mild irritant. Thus, using same individual testing animal on repeated dermal corrosion testing showed the effect of resistance to detergent samples and the animal provided aless-sensitive respond for the same sample.
\end{abstract}

Keywords: corrosion test, irritation, dermal, rabbit, erythrema, oedema

' Pusat Penelitian dan Pengembangan Kualitas dan Laboratorium Lingkungan - Kementerian Lingkungan Hidup dan Kehutanan (P3KLL KLHK) di Kawasan PUSPIPTEK Gedung 210 Serpong - Tangerang, Banten Telp/faks. 021-7560981, email: emc_acdep@yahoo.com 


\section{PENDAHULUAN}

Pengelolaan limbah bahan berbahaya dan beracun (B3) diatur dalam Peraturan Pemerintah Nomor 101 Tahun 2014 (1) dan selanjutnya tata cara uji karakteristik limbah B3 dijabarkan dalam Peraturan Menteri Lingkungan Hidup dan Kehutanan (PerMenLHK) no 55 tahun 2015 (2). Peraturan Menteri Lingkungan Hidup (PermenLH) No 55 Tahun 2015 pasal 9 menyatakan untuk menguji suatu limbah termasuk B3 atau bukan, maka dilakukan uji karakteristik, salah satunya uji dermal untuk pengujian sifat korosif pada kulit setelah dilakukan pemberian sampel (2). Pengujian toksikologi dimaksudkan untuk menjaga keselamatan manusia dari berbagai kemungkinan dampak yang ditimbulkan oleh berbagai jenis bahan kimia (termasuk produk dan limbah). Paparan tersebut bisa terjadi secara kebetulan, sengaja maupun tidak sengaja. Salah satu efek dari paparan dan kontak secara tak sengaja dengan bahan kimia adalah iritasi kulit. Secara umum, respon fisiologi terhadap rangsangan bahan kimia adalah iritasi, yang meliputi perubahan fisik misalnya kulit berwarna kemerahan/ eritema (erythema) di area lokal dan bengkak (oedema/edema), dan atau sensasi subyektif seperti gatal pada seluruh atau sebagian tubuh (pruritus) dan kesakitan (3).

Penentuan efek iritasi suatu bahan kimia dalam hewan uji memberikan informasi terhadap masyarakat dan perlindungan terhadap kemungkinan bahaya yang mungkin timbul apabila terpapar pada manusia. Lebih lanjut, data yang dihasilkan dimanfaatkan untuk tujuan klasifikasi dan registrasi bahan. Terdapat beberapa panduan metode pengujian efek iritasi seperti Organization for Economic Cooperation and Development (OECD), European Economic Community (4) dan Federal Insecticide, Fungicide, and Rodenticide Act (FIFRA) (5). Pengenalan OECD Guideline No. 404 menunjukkan adanya pengurangan jumlah hewan uji yang digunakan dalam pengujian iritasi kulit (6).

Dunia penelitian toksikologi umumnya telah mereduksi penggunaan hewan uji secara bertahap dengan alasan mempertimbangkan kesejahteraan hewan (animal welfare) atau kode etik pengujian (7). Penelitian yang melibatkan hewan dalam jumlah banyak telah menjadi perdebatan sengit di berbagai negara. Dengan demikian, aturan kode etik yang meliputi penggunaan hewan uji, validitas pengujian dermal, dan kebutuhan untuk validasi preklinis yang lebih efisien membuka ide untuk mengembangkan metode alternatif untuk pengujian iritasi (3). Pengujian karakteristik limbah B3 berdasarkan PerMen LHK no 55 tahun 2015 dilakukan melalui pendekatan bertahap. Pengujian menggunakan hewan hanya diperlukan sebagai langkah untuk mengkonfirmasi hasil negatif dari pengujian karakteristik fisika dan kimia yang dilakukan sebelumnya.

Iritasi kulit akut dievaluasi secara in vivo pada hewan uji setelah dilakukan pencukuran bulu. Sampel yang akan diuji dioleskan pada kulit hewan uji. Timbulnya edema maupun erythema akibat reaksi sampel dengan kulit dievaluasi pada 4, 24, 48, dan 72 jam setelah pengujian (6). Sistim skoring akan mengklasifikasikan jenis bahan non iritan sampai sangat iritan. Sejumlah model hewan in vivo digunakan sebagai alternatif tes Draize, antara lain dengan menggunakan marmot, mencit, dan tikus (8). 
Pemilihan deterjen sebagai salah satu bahan yang umum digunakan sebagai kontrol positif yang termasuk dalam kelompok dishwasher powder (9). Sodium Lauryl Sulfate-SLS merupakan komponen kimia yang banyak ditemukan dalam deterjen, bersama dengan sodium laureth sulfateSLES dan ammonium laurel sulfate-ALS. Laboratorium menggunakan SLS sebagai kontrol positif karena memberikan dampak terhadap kulit. Lebih dari 99\% SLS mudah terurai menjadi komponen non-toksik sesuai standar OECD 301 namun tetap memberikan respon iritasi terhadap kulit (10). Berdasarkan MSDS dan OECD screening ingredient data set, SLS diketahui memiliki LD50-oral akut pada tikus sebesar $1288 \mathrm{mg} / \mathrm{kg}$, dermal akut pada kelinci sebesar 2000-20000 mg/kg, dan LC50-toksisitas akuatik pada ikan selama 96 jam sebesar 1-12 mg/L (10).

\section{METODOLOGI}

Pengujian korosi dermal dilakukan berdasarkan OECD Guideline No. 404.
Hewan uji yang digunakan dalam kegiatan ini adalah kelinci albino sehat berbobot 2 $\mathrm{kg}$. Hewan diaklimatisasi selama seminggu di laboratorium, kemudian bulu pada bagian dorsal (punggung) dicukur. Bahan yang digunakan untuk paparan pengujian dermal berupa contoh uji limbah yang tidak diketahui karakteristiknya, kontrol positif (deterjen merek X) untuk memperlihatkan efek iritasi yang jelas, dan kontrol negatif (akuades).

Pengujian dilakukan pada individu hewan yang sama setelah selang 30 hari antara pengujian pertama dengan pengujian kedua. Diberikan jeda waktu bagi hewan setelah 14 hari pengamatan reversibilitas dan tidak terbentuk luka yang tidak sembuh seperti semula (11). Titik pengujian berada pada lokasi yang berbeda dalam satu area pencukuran. Pemaparan pengujian kedua dilakukan pada posisi yang berseberangan baik untuk lokasi nomor pemaparan contoh uji maupun kontrol (Gambar 2).

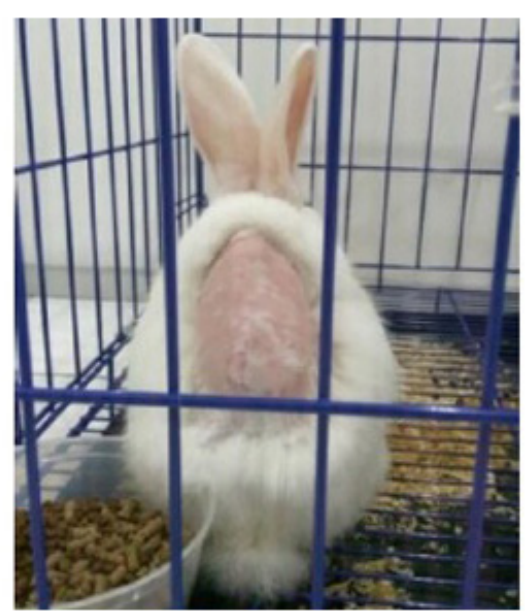

(a) Hewan Uji

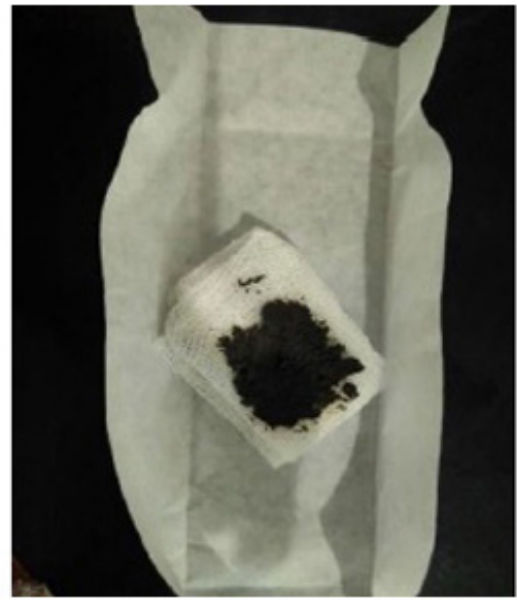

(b) Sempel Limbah

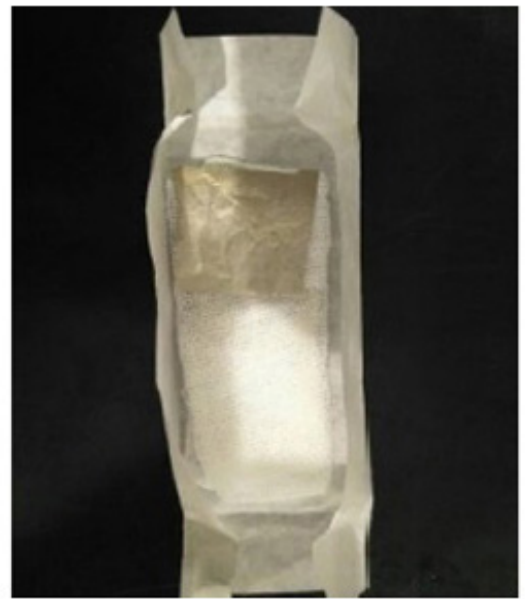

(c) Kontrol Positif

Gambar 1. Hewan Uji dan Bahan Pengujian

Sumber : Dokumentasi Laboratorium Toksikologi, P3KLL Serpong 


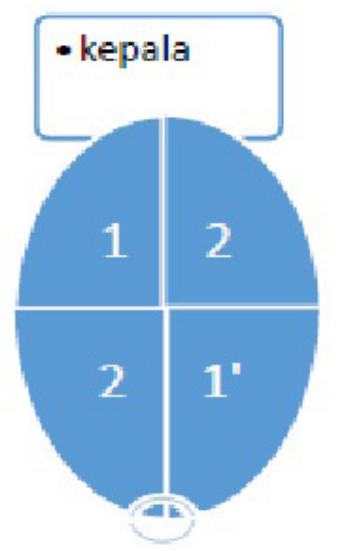

Keterangan:

Kepala

Lokasi pemaparan sampel uji

(1) aplikasi pengujian ke 1

(1') aplikasi pengujian ke 2

2. Lokasi pemaparan kontrol

(+) kontrol positif

(-) kontrol negatif

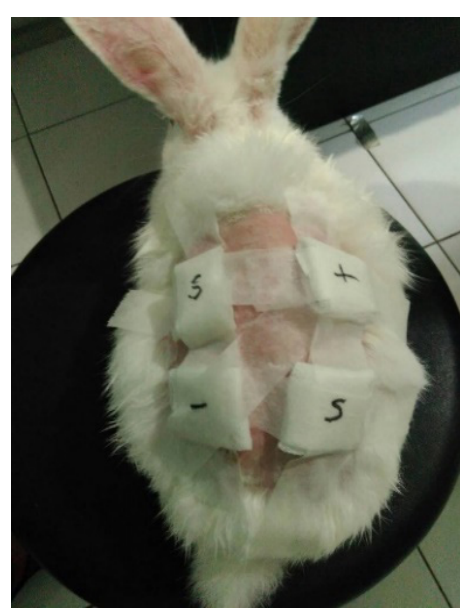

Classification of Chemical 2009, seperti pada Tabel 1. Kriteria tersebut digunakan untuk mengelompokkan bahan uji berbahaya.
Pengamatan pengujian terhadap hewan uji dilakukan secara visual. Hasil uji dievalusi berdasarkan kriteria bahaya dari Globally Harmonized System (GHS) for the

Tabel 1. Kriteria penggolongan sampel uji yang bersifat korosif/iritan pada kulit (12)

\begin{tabular}{|c|c|c|}
\hline Kategori & & Kriteria \\
\hline Kategori 1, Korosif & $1 \mathrm{~A}$ & $\begin{array}{l}\text { Respon korosif terjadi pada pemaparan selama } \leq 3 \text { menit; pengamatan selama } \leq 1 \text { jam pada } \\
\geq 1 \text { dari } 3 \text { ekor hewan uji; } \\
\text { Respon korosif terjadi pada pemaparan selama } \leq 3 \text { menit sampai } \leq 1 \text { jam; pengamatan } \\
\text { selama } \leq 14 \text { hari pada } \geq 1 \text { dari } 3 \text { ekor hewan uji; } \\
\text { Respon korosif terjadi pada pemaparan selama } \leq 1 \text { jam sampai } \leq 4 \text { jam; pengamatan selama } \\
\leq 14 \text { hari pada } \geq 1 \text { dari } 3 \text { ekor hewan uji. }\end{array}$ \\
\hline $\begin{array}{l}\text { Kategori 2, } \\
\text { Iritan }\end{array}$ & iii & $\begin{array}{l}\text { Skor rata-rata untuk eritema/edema } \geq 2,3 \text { sampai } \leq 4,0 \text { (setelah pemaparan selama } 4 \text { jam, } \\
\text { pengamatan selama } 3 \text { hari pada minimal } 2 \text { dari } 3 \text { ekor hewan uji atau; } \\
\text { Inflamasi tidak sembuh sampai hari ke } 14 \text { minimal pada } 2 \text { ekor hewan uji, terjadi alopecia } \\
\text { pada daerah tertentu, hyperplasia, scaling atau; } \\
\text { Terdapat efek eritema/edema yang jelas pada } 1 \text { ekor hewan uji walau tidak memenuhi } \\
\text { kiteria di atas. }\end{array}$ \\
\hline $\begin{array}{l}\text { Kategori 3, } \\
\text { Iritan ringan }\end{array}$ & & $\begin{array}{l}\text { Skor rata-rata untuk eritema/edema } \geq 1,5 \text { sampai } \leq 2,3 \text { setelah pemaparan selama } 4 \text { jam, } \\
\text { pengamatan selama } 3 \text { hari setelah terjadinya reaksi kulit tetapi tidak termasuk kategori } \\
\text { seperti di atas, pada minimal } 2 \text { dari } 3 \text { ekor hewan uji }\end{array}$ \\
\hline $\begin{array}{l}\text { Kategori } 4 \\
\text { Non iritan }\end{array}$ & & $\begin{array}{l}\text { Skor rata-rata untuk eritema/edema } \leq 1,4 \text { setelah pemaparan selama } 4 \text { jam, pengamatan } \\
\text { selama } 3 \text { hari setelah terjadinya reaksi kulit tetapi tidak termasuk kategori seperti di atas. }\end{array}$ \\
\hline
\end{tabular}

Keterangan : alopecia : kebotakan, hyperplasia : peningkatan jumlah sel pada organ tertentu, scaling : pengerakan

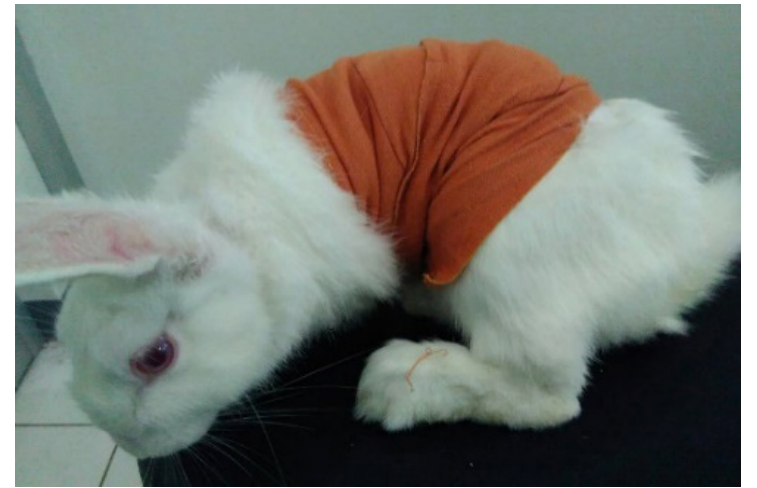

Sumber: Dokumentasi Laboratorium Toksikologi, P3KLL-Serpong
Gambar 3. Pembebatan hewan uji setelah aplikasi Pembebatan hewan uji dilakukan untuk menempelkan bahan uji pada permukaan kulit hewan uji setelah ditutup kasa dan plester, dan mencegah agar bahan uji tidak bergeser. 
Penilaian terhadap reaksi iritasi edema dan eritema yang terjadi digunakan skoring pembentukan mengikuti OECD, dengan lama pengamatan selama 72 jam sebagai berikut:

\section{HASIL DAN PEMBAHASAN}

Hasil pengamatan pengujian dermal terhadap perlakuan sampel limbah

Hewan kelinci dan marmot dapat diprediksikan sebagai model untuk skrining awal dampak

Tabel 2. Pembentukan skoring eritema dan edema:

\begin{tabular}{lc}
\hline Pembentukan Eritema & Nilai skor \\
\hline Tidak ada eritema & Skor 0 \\
Eritema sangat kecil (hampir tidak dapat dibedakan) & Skor 1 \\
Eritema terlihat jelas & Skor 2 \\
Eritema sedang sampai parah & Skor 3 \\
Eritema parah (merah daging) sampai pembentukan eschar yang menghambat penilaian & Skor 4 \\
\hline Pembentukan Edema & \\
\hline Tidak ada edema & Skor 0 \\
Edema sangat kecil (hampir tidak dapat dibedakan) & Skor 1 \\
$\begin{array}{l}\text { Edema kecil (batas area terlihat jelas) } \\
\text { Edema tingkat menengah (luasnya bertambah sekitar 1 mm) }\end{array}$ & Skor 2 \\
Edema parah (luas bertambah lebih dari 1 mm dan melebar melebihi area pemaparan & Skor 4 \\
oleh sampel uji) & \\
\hline
\end{tabular}

Evaluasi seluruh pengaruh reversibilitas yang teramati dilakukan dalam periode waktu yang mencukupi. Hewan uji diamati selama tidak kurang dari 14 hari setelah tempelan dibuka. Akan tetapi pengujian harus diakhiri saat hewan menunjukkan tanda-tanda kesakitan yang parah. Apabila gejala reversibilitas terlihat sebelum 14 hari, maka pengujian harus dihentikan saat itu juga. bahan kimia terhadap iritasi kulit (13), demikian pula halnya dalam pengujian sampel limbah.

Pengujian menggunakan sampel limbah yang sama menggunakan hewan uji yang sama dalam periode berbeda, dimana (a) pengujian pertama dan (b) pengujian kedua. Pengujian kedua (b) dilakukan pada hewan uji yang

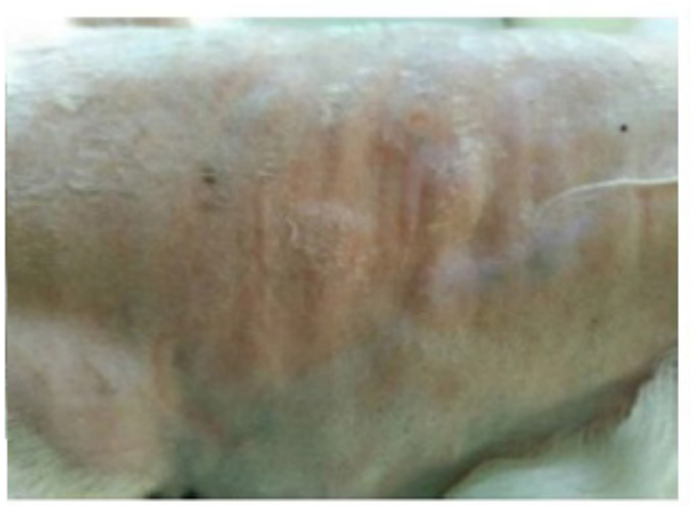

(a)

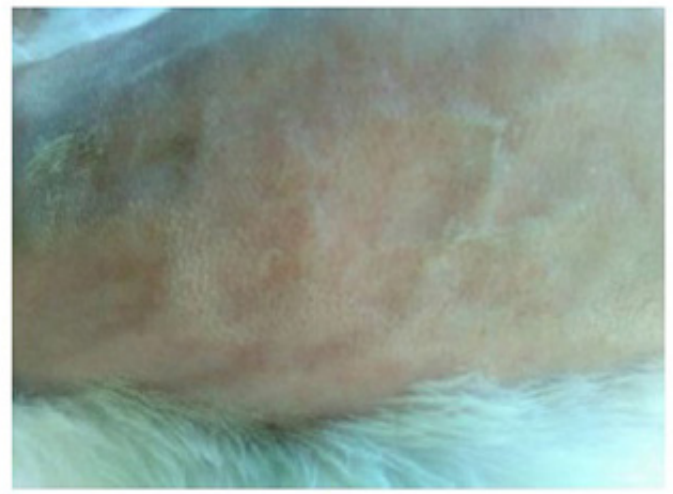

Sumber:

Dokumentasi Laboratorium Toksikologi, P3KLL-Serpong

Gambar 4. Hasil pengamatan dermal pada perlakuan sampel

Pengujian menggunakan sampel limbah yang sama menggunakan hewan uji yang sama dalam periode berbeda, dimana (a) pengujian pertama dan (b) pengujian kedua. Pengujian kedua (b) dilakukan pada hewan uji yang sama setelah selang 30 hari. Pengambilan gambar masing-masing dilakukan setelah 4 jam pemaparan. 
sama setelah selang 30 hari. Pengambilan gambar masing-masing dilakukan setelah 4 jam pemaparan.

\section{Hasil pengamatan pengujian dermal terhadap kontrol positif}

Timbulnya eritema/edema akibat adanya proses iritasi menjadi poin penting karena pengamatan terhadap pengujian dilakukan secara visual. Hasil pengujian iritasi menggunakan bahan deterjen (X) memperlihatkan hasil yang berbeda setelah 4 jam pengujian. Dalam penggunaan kontrol positif pada pengujian dermal, umumnya bahan-bahan kimia untuk kebutuhan rumah tangga atau industri dipaparkan selama 4 jam pada permukaan tubuh kelinci yang telah dicukur. Respon kulit dilakukan skoring setelah 1, 4, 24, 48 dan 72 jam setelah pemaparan. Hasil pengujian sebanyak 2 kali pengujian dengan 3 hewan ulangan yang sama menghasilkan data rata-rata seperti tertera pada tabel 3;

Nilai skoring akhir dari dua pengujian menunjukkan kesimpulan yang berbeda dari lokasi perlakuan yang berbeda dalam satu individu. Pada perlakuan pertama terlihat jelas bahwa adanya edema dan eritema. Iritasi pada Gambar 5(a) memperlihatkan hasil yang termasuk pada Tabel 1. ke dalam kategori 3 , iritasi ringan, yaitu skor rata-rata untuk eritema/edema sebesar 2,1 (setelah pemaparan selama 4 jam, pengamatan selama 3 hari, pada minimal 2 dari 3 ekor hewan uji) (8). Hasil tersebut dengan jelas memperlihatkan terjadinya iritasi yang dapat diamati.

Tabel 3. Hasil Pengamatan

\begin{tabular}{cccccc}
\hline \multirow{2}{*}{ Pengujian } & Sampel & Eritema & Edema & Rerata hasil skoring & Kesimpulan \\
\hline \multirow{2}{*}{1} & Limbah & 0 & 0 & 0 & Non iritan \\
& Kontrol $(+)$ & 2,3 & 1,9 & 2,1 & Iritasi ringan \\
\hline \multirow{2}{*}{2} & Limbah & 0 & 0 & 0 & Non iritan \\
& Kontrol $(+)$ & 1.3 & 1,6 & 1,4 & Non iritan \\
\hline
\end{tabular}

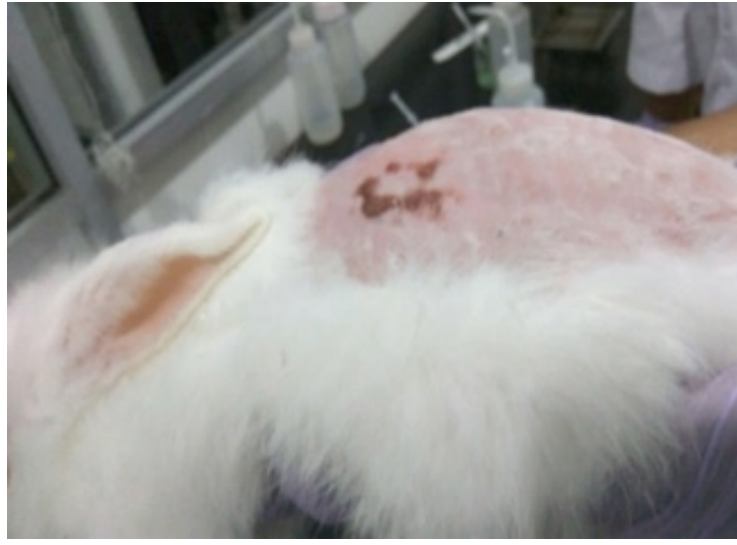

(a)

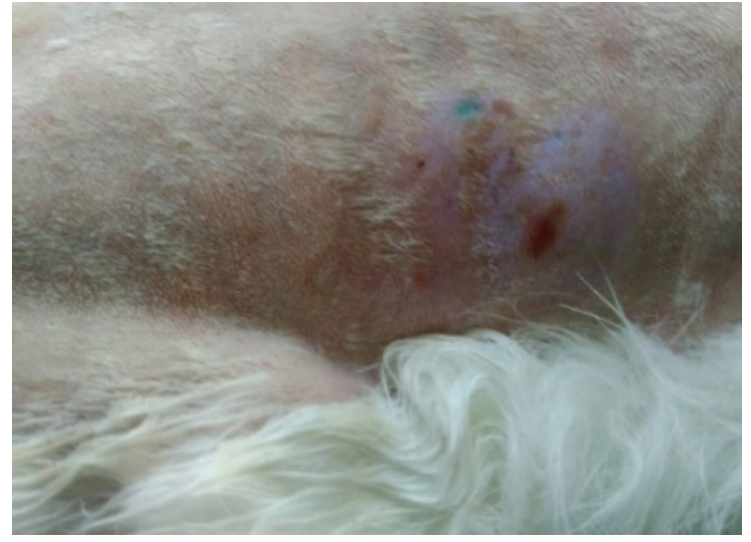

(b)

Gambar 5. Hasil pengujian dermal terhadap kontrol positif

Pengujian menggunakan kontrol positif (deterjen) yang sama menggunakan hewan uji yang sama dalam periode berbeda, dimana (a) merupakan pengujian pertama dan (b) pengujian kedua. Pengujian kedua dilakukan setelah selang 30 hari. Pengambilan gambar masingmasing dilakukan setelah 4 jam pemaparan.

Sumber: Dokumentasi Laboratorium Toksikologi, P3KLL-Serpong 
Pada pengujian kedua meskipun dengan individu hewan yang sama, penempatan sampel dilakukan di lokasi yang berseberangan dengan lokasi pada pengujian pertama. Gambar 5(b) memperlihatkan hasil iritasi terlihat lebih samar dengan kategori 4, non iritan. Iritasi yang terjadi tidak sama dengan pengujian pertama, dengan luasan edema yang relatif lebih kecil pada perlakuan kedua dimana area yang terpapar dan eritema terlihat lebih meluas. Pada kulit tersebut juga masih ditemukan bentuk granul dalam sisa paparan yang menunjukkan bahwa homogenisasi sampel deterjen tidak sempurna.

Sejumlah bahan menyebabkan reaksi berbeda satu sama lain. Beberapa jenis menyebabkan adanya kerusakan jaringan pada daerah yang diujikan pada kelinci, namun ternyata memiliki reaksi berbeda terhadap kulit manusia (13). Penelitian terdahulu umumnya mendeskripsikan hasil pengujian untuk bahan baku deterjen secara individu dimana masing-masing memberikan reaksi beragam. Pengamatan dalam jangka 1 jam umumnya belum memberikan respon reaksi yang sangat jelas, namun setelah 4 jam reaksi iritasi/korosifitas akan lebih terdeteksi secara visual. Sodium tripolifosfat $\left(\mathrm{Na}_{5} \mathrm{P}_{3} \mathrm{O}_{10}\right)$ dan natrium karbonat $\left(\mathrm{Na}_{2} \mathrm{CO}_{3}\right)$ yang umum ditemukan dalam deterjen menyebabkan vesikulasi (kulit melepuh) di area yang dirusak pada satu dari enam manusia, namun hanya menghasilkan sedikit reaksi pada kulit binatang (13).

Alkalinitas dari produk deterjen pencuci akan menentukan tingkat iritasi yang dihasilkan. Tingkat kerusakan pada jaringan bergantung pada $\mathrm{pH}$ ( $\mathrm{pH}$ terukur 10,67), konsentrasi, sifat fisik, serta lama dan jumlah paparan $(14,15)$. Produk deterjen yang mengandung silikat atau metasilikat bersifat basa dan korosif, sedangkan yang mengandung enzim dan oksidan cenderung memiliki pH lebih rendah dan bersifat lebih aman (9). Pengamatan visual menunjukkan terjadinya perubahan bentuk eritema/oedema yang memudar seiring pertambahan waktu, dimana tubuh individu hewan uji secara alamiah memberikan respon pemulihan.

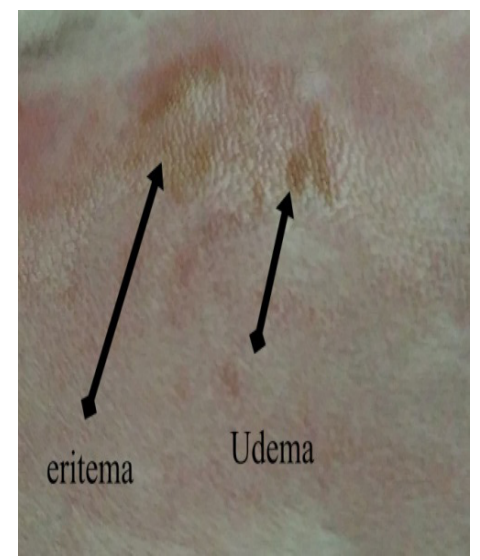

(a) 24 jam

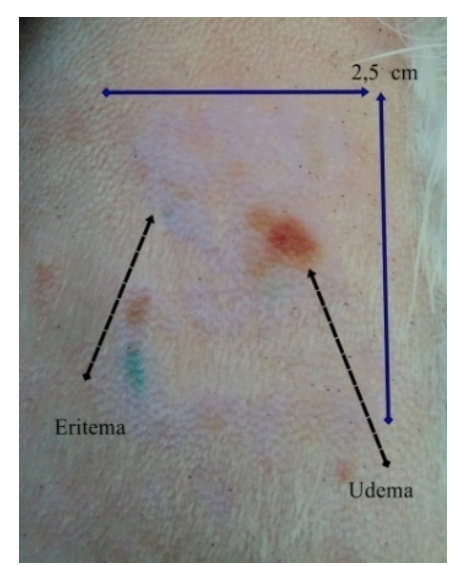

(a) 48 jam

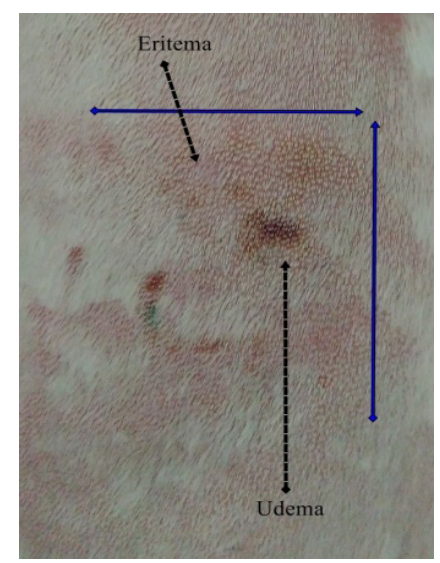

(a) $72 \mathrm{jam}$

Gambar 6. Visualisasi eritema dan edema pada hewan uji

Hasil visualisasi pada pengujian pertama menggunakan kontrol positif (deterjen) pada pengamatan (a) 24 jam, (b) 48 jam, dan (c) 72 jam.

Sumber: Dokumentasi Laboratorium Toksikologi, P3KLL-Serpong 


\section{Pengamatan Proses Pemulihan}

Dalam kajian ini, periode pemulihan berlangsung selama 20 hari. Setelah 14 hari pengujian, umumnya bulu kelinci akan mulai tumbuh kembali secara sempurna setelah 30 hari dari waktu pengujian dan luka mulai berangsur pulih. Pengamatan terhadap hewan uji dilakukan secara bertahap untuk melihat terjadinya proses pemulihan (recovery) untuk mengevaluasi pengaruh reversibilitas. Efek racun bahan kimia kerap kali bersifat mudah berbalik (reversible) maupun tidak dapat berbalik (irreversible). Apabila suatu bahan kimia menyebabkan luka patologis terhadap jaringan, kemampuan jaringan untuk melakukan regenerasi menentukan sifat efek yang mudah atau tidak dapat berbalik (17).

Pada Gambar 7 terlihat adanya perbedaan lapisan kulit kelinci pada area setelah dilakukan pencukuran bulu selang 30 hari kemudian.

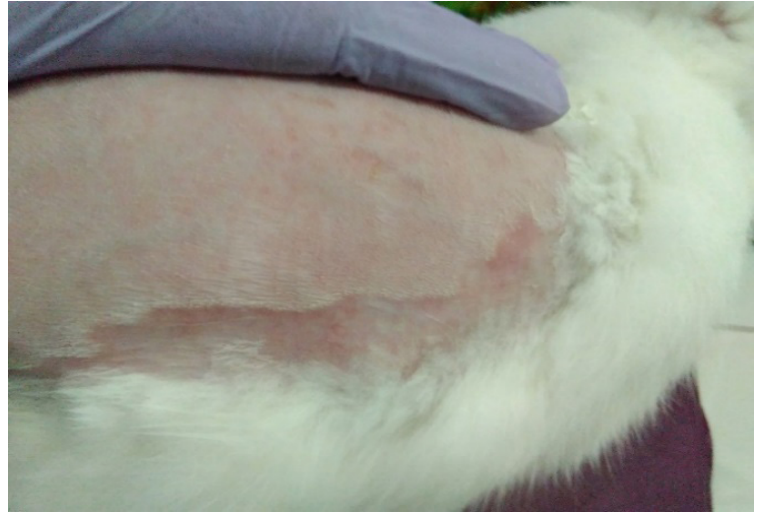

Gambar 7. Area pencukuran bagian dorsal kelinci pada pengujian kedua

Sumber: Dokumentasi Laboratorium Toksikologi, P3KLL-Serpong

Area yang lebih merah memperlihatkan bagianyang belum pernah dilakukan pencukuran. Individu kelinci tersebut memperlihatkan adanya efek resistansi dan relatif tidak terlalu sensitif terhadap bahan kimia serupa yang dipaparkan kembali setelah selang 30 hari.

Berikut adalah dokumentasi visual proses pemulihan kelinci pada pengujian pertama.

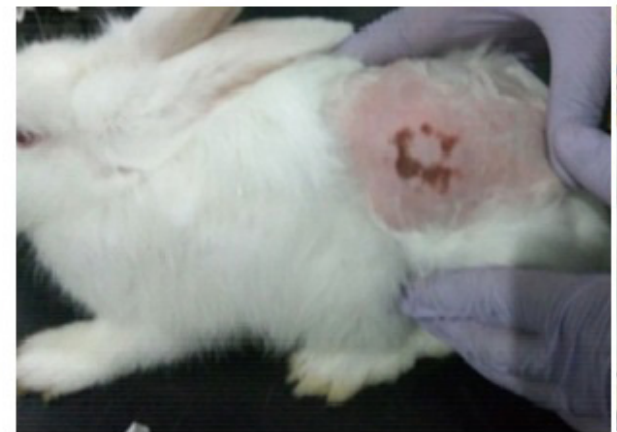

(a) Hari ke 1

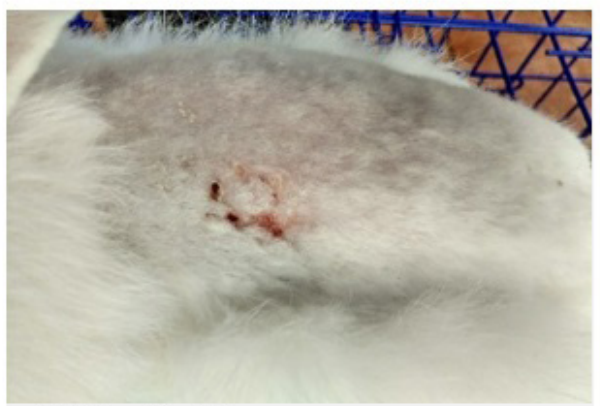

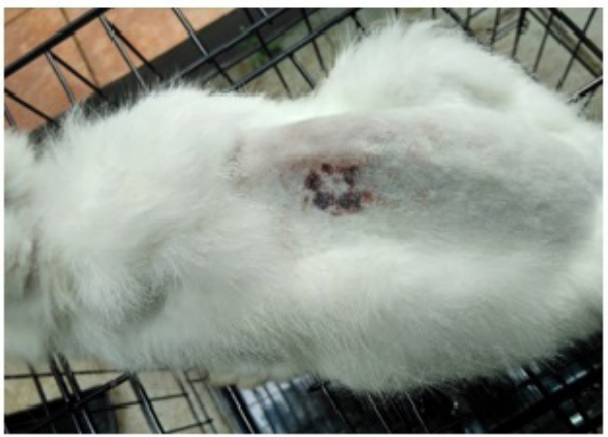

(a) Hari ke 6

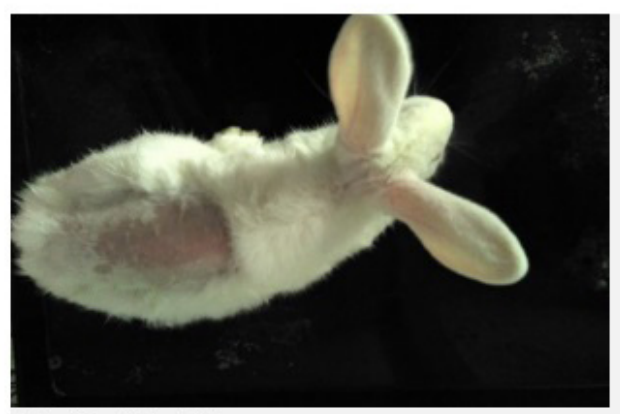

(b) Hari ke 13

(b) Hari ke 20

Sumber:

Dokumentasi

Laboratorium

Toksikologi,

P3KLL-Serpong

Gambar 8. Pengamatan hewan uji selama proses pemulihan

Pengambilan gambar diambil secara acak setelah dilakukan pengujian pertama, dengan urutan hari ke-1, 6, 13, dan 20 


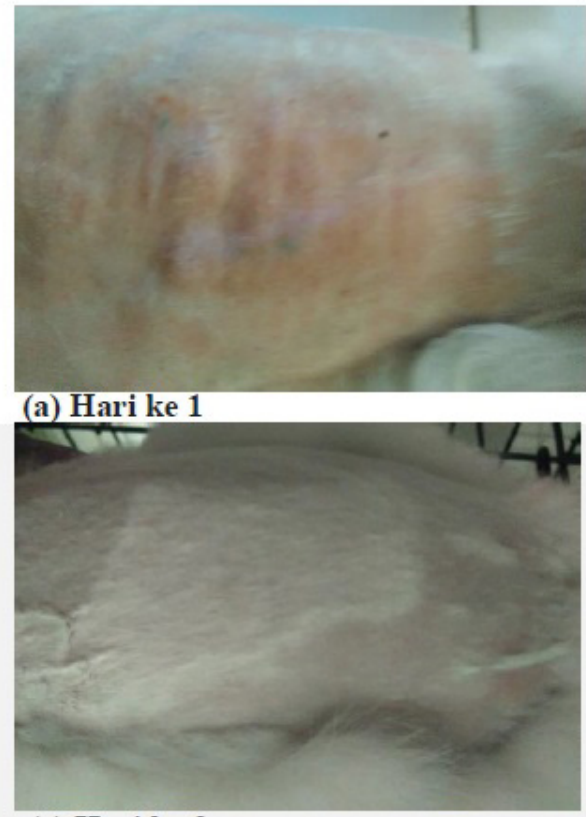

(c) Hari ke 3

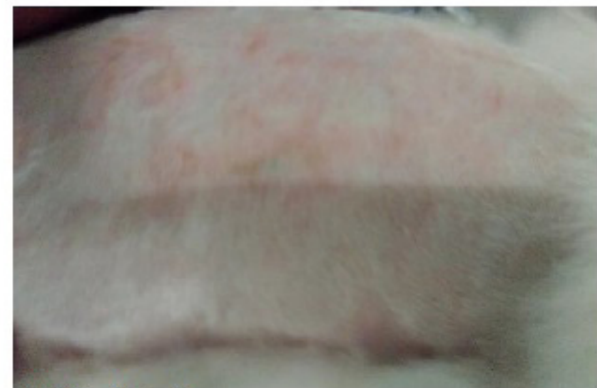

(a) Hari ke 2

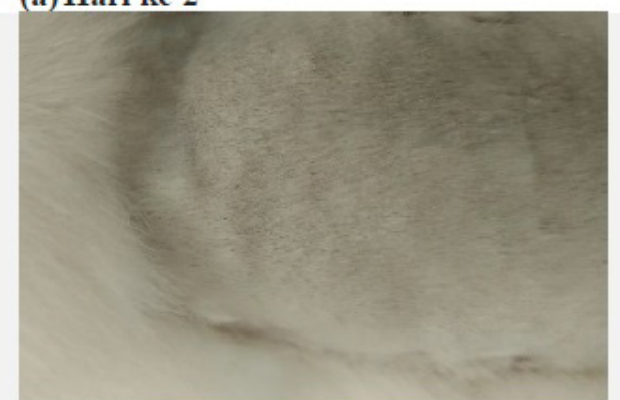

(d) Hari ke 13

Gambar 9. Pengamatan hewan uji selama proses pemulihan

Pengambilan gambar diambil secara acak setelah dilakukan pengujian kedua, dengan urutan hari ke-1, 2, 3, dan 13

Sumber: Dokumentasi Laboratorium Toksikologi, P3KLL-Serpong

Pada pengujian kedua setelah dilakukan pembersihan terhadap sisa sampel uji, respon iritasi pada individu kelinci tersebut terlihat jauh lebih samar dibandingkan dengan pengujian pertama.

Pada kajian ini, hewan uji kelinci memberikan respon dalam proses pemulihan akibat luka iritasi yang ditimbulkan oleh sampel deterjen selama perlakuan pengujian. Kegiatan ini membuktikan bahwa penggunaan individu yang sama untuk pengujian dermal tidak dapat memberikan respon yang serupa. Dalam suatu pengujian dermal digunakan 3 ekor hewan uji yang berbeda dalam satu pengujian. Masing-masing individu hewan akan memberikan respon yang beragam, namun hasil pengamatan pengujian akan disimpulkan dalam suatu kriteria yang telah ditetapkan.

\section{SIMPULAN}

Pengujian dengan selisih antara pengujian selang 30 hari menggunakan deterjen menghasilkan variasi hasil, yaitu pada pengujian pertama mengalami iritasi sedang sementara pada pengujian kedua mengalami iritasi ringan.Dengan demikian, penggunaan individu hewan uji yang sama tidak disarankan dalam pengujian korosif dermal karena memberikan hasil sensitivitas yang berbed.

\section{DAFTAR PUSTAKA}

(1) KLH. Peraturan pemerintah (PP) No 101 Tahun 2014 tentang pengelolaan limbah bahan berbahaya dan beracun (B3). Jakarta2014.

(2) KLHK. PerMen LHK No 55 Tahun 2015 Tata cara uji karakteristik limbah bahan berbahaya dan beracun Jakarta2015. 
(3) Vinardell M, Mitjans M. Alternative methods for eye and skin irritation tests: an overview. Journal of pharmaceutical sciences. 2008;97(1):46-59.

(4) Beech IB, Sunner J. Biocorrosion: towards understanding interactions between biofilms and metals. Current opinion in Biotechnology. 2004;15(3):181-6.

(5) Gfeller W, Kobel W, Seifert G. Overview of animal test methods for skin irritation. Food and Chemical Toxicology. 1985;23(2):165-8.

(6) OECD. Guidelines for the testing of chemicals. acute dermal irritation/ corrosion. In: Publicationw EHaS, editor. Paris2015.

(7) Watts G. Animal use in toxicity studies London2005. Available from: http:// nuffieldbioethics.org/project/animalresearch.

(8) Sekizawa J, Yasuhara K, Suyama Y, Yamanaka S, Tobe M, Nishimura M. A simple method for screening assessment of skin and eye irritation. The Journal of toxicological sciences. 1994;19(1):25-35.

(9) Cressey P, Pattis I. Health risk assessment: Dishwasher powder. Institute of Environmental Science and Research NZ, 2014.

(10) Bondi CA, Marks JL, Wroblewski LB, Raatikainen HS, Lenox SR, Gebhardt KE. Human and environmental toxicity of sodium lauryl sulfate (SLS): evidence for safe use in household cleaning products. Environmental health insights. 2015;9:27.
(11) Pozo K, Harner T, Shoeib M, Urrutia R, Barra R, Parra O, et al. Passivesampler derived air concentrations of persistent organic pollutants on a North-South transect in Chile. Environmental science \& technology. 2004;38(24):6529-37.

(12) UN. Globally Harmoinized System for the classification and labelling of chemical. Third ed2009.

(13) Nixon G, Tyson C, Wertz W. Interspecies comparisons of skin irritancy. Toxicology and applied pharmacology. 1975;31(3):481-90.

(14) Bertinelli A, Hamill J, Mahadevan M, Miles F. Serious injuries from dishwasher powder ingestions in small children. Journal of paediatrics and child health. 2006;42(3):129-33.

(15) Kikendall J. Caustic ingestion injuries. Gastroenterology Clinics of North America. 1991;20(4):847-57.

(16) NICNAS. Human health tier II assessment for hypochlorous acid, sodium salt. CAS number: 768152-9. In: Australia DoH, editor. Sydney2017.

(17) Eaton DL, Klaassen CD. Casarett and Doull's Toxicology: The basic science of poisons. 8th, editor. New York: McGraw Hill; 2013. 


\section{UCAPAN TERIMA KASIH}

Dewan Redaksi mengucapkan terima kasih kepada:

1. Prof. (r) DR. Yanni Sudiyani - LIPI

2. Prof. (r) DR. Gustan Pari - KLHK

3. Prof. DR Hefni Effendi - IPB

4. Prof. (r) DR. Chairil Anwar Siregar - KLHK

5. DR. Budi Haryanto - UI

6. Prof. (r) DR. Muhayatun Santosa - Batan

Sebagai Mitra Bestari atas kesediaannya melakukan review pada Jurnal Ecolab Volume 12 Nomor 1, Januari 2018.

Januari 2018

Dewan Redaksi

Ecolab Jurnal Kualitas Lingkungan Hidup 